\title{
Študijski in profesionalni prehodi zamejskih Slovencev iz Italije: primer študentov Pedagoške fakultete Univerze na Primorskem
}

\author{
Maja Mezgec \\ Univerza na Primorskem \\ maja.mezgec@pef.upr.si \\ Barbara Baloh
Univerza na Primorskem
barbara.baloh@pef.upr.si
}

V prispevku je predstavljena etnografska raziskava o zamejskih študentih Pedagoške fakultete Univerze na Primorskem. Analizo usmerjamo v njihovo prehajanje med dvema izobraževalnima sistemoma; začenjamo z analizo prehoda iz srednješolskega sistema v Italiji v visokošolski sistem v Sloveniji in zaključimo s prehodom na zaposlitveni trg v Italiji ob zaključku študija. Namen prispevka je izpostaviti vrzeli pri prehodih zamejskih študentov oz. Slovencev iz Italije, ki se odločajo za študij v Sloveniji in se po njegovem zaključku vključujejo na trg dela v Italiji, ter oblikovati možne predloge izboljšave, da zamejski študentje ne bi postali žrtve dveh sistemov.

Ključne besede: zamejski študentje, priznavanje nazivov, priznavanje poklicne kvalifikacije, študijske praksa, čezmejni prostor

\section{Uvod in raziskovalni problem}

Evropski integracijski procesi so bistveno oblikovali obmejni prostor med Slovenijo in Italijo (Bufon 2019a; 2019b). Med drugim so olajšali čezmejno povezovanje in okrepili pretočnost državljanov obeh mejnih držav. Med kazalnike omenjenih sprememb spadajo tudi povečan obseg dnevnih migrantov, ki se vozijo na delo v sosednjo državo (Mezgec 2008), nakup nepremičnin čez mejo (Jagodic 2014) in šolanje ter študij v sosednji državi (Mezgec 2019; Baloh in Mezgec 2017). Integracija obmejnega prostora pa se kaže tudi na področju storitev in drugih gospodarskih dejavnosti. Tudi na področju izobraževanja opažamo večjo pretočnost: tako na ravni zamejskih učencev in študentov kot tudi učnega kadra. $V$ pričujočem prispevku bomo pozornost usmerili v čezmejne študente in njihovo prehajanje med dvema izobraževalnima sistemoma. Predstavili bomo študijo primera študentov Pedagoške fa- 
kultete Univerze na Primorskem ( $v$ nadaljevanju UP PEF). Analizo prehodov bomo začeli s prehodom iz srednješolskega sistema v Italiji in zaključili s prehodom na zaposlitveni trg v Italiji ob zaključku študija. Gre za študente, ki so obiskovali šole s slovenskim učnim jezikom v Italiji in se v Sloveniji usposabljajo za delo vzgojitelja oz. učitelja z namenom, da se ob koncu študija zaposlijo $v$ vrtcih in šolah s slovenskim učnim jezikom v Italiji (Krmac 2019).

Pri analizi smo izhajali iz ugotovitev predhodne raziskave (Baloh in Mezgec 2017; Krmac 2019), v kateri smo ugotavljali, zakaj se maturanti s Tržaškega in Goriškega odločajo za študij na UP PEF ter katere težave se porajajo ob koncu študija s priznavanjem pridobljenih strokovnih nazivov.

Uvodoma velja omeniti, da je povezovanje s Slovenci po svetu izrecno omenjeno v Strategiji internacionalizacije slovenskega visokega šolstva 20162020 (Vlada Republike Slovenije 2016, 5): „Visoko šolstvo je lahko tudi eden ključnih vzvodov za mednarodno promocijo Slovenije, vzpostavljanje strateških povezav s partnerji v tujini, krepitev povezav s Slovenci po svetu ter pomoč in podporo razvoju družbe in kakovosti življenja v regijah v razvoju.«

\section{Namen in raziskovalna vprašanja}

Namen prispevka je izpostaviti zaplete pri prehodih zamejskih študentov oz. Slovencev iz Italije, ki se odločajo za študij v Sloveniji in se po zaključku študija vključujejo $v$ trg dela v Italiji. Pri tem gre izpostaviti, da gre za prehode med mejnima državama, s katerima imajo močne kulturne in jezikovne vezi. Oblikovati želimo tudi nabor predlogov, $z$ upoštevanjem katerih bi lahko soudeleženi deležniki in nosilci interesov prispevali k lažjemu prehajanju zamejskih študentov med izobraževalnima sistemoma ter zaposlitvenima svetovoma dveh mejnih držav. Skozi analizo zbranih podatkov so nas vodila spodnja raziskovalna vprašanja.

1. Kateri so ključni prehodi zamejskih študentov, ki se odločajo za študij na programu Predšolska vzgoja ali Razredni pouk na UP PEF, in s katerimi težavami se soočajo ob prehodih?

2. V kolikšni meri so vzgojitelji in učitelji, ki so študij zaključili na UP PEF, usposobljeni za delo na šolah in vrtcih s slovenskim učnim jezikom $v$ Italiji? Katera znanja oz. poklicne kompetence pogrešajo?

3. Kako bi lahko ublažili težave zamejskih študentov UP PEF pri prehodih?

\section{Metodologija}

Raziskava je temeljila na deskriptivni in kavzalno-neeksperimentalni metodi empiričnega pedagoškega raziskovanja. Gre za etnografsko raziskavo (Štem- 
berger 2020) o zamejskih študentih na UP PEF, ki smo jo opravili v daljšem časovnem obdobju, z zbiranjem podatkov iz različnih virov (opazovanje, intervjuji, pogovori, dokumenti) ter analizo podatkov v kontekstu vsakdanjega življenja. V raziskavo so vključeni študentje UP PEF, ki so obiskovali srednjo šolo s slovenskim učnim jezikom v Italiji in se usposabljajo za poklic vzgojitelja oz. učitelja razrednega pouka. Za potrebe raziskave smo uporabili triangulacijo kvalitativnih podatkov, ki smo jih pridobili z opazovanjem z udeležbo $v$ vlogi tutorja za čezmejne študente, s pogovori z vključenimi v raziskavo, $z$ interno dokumentacijo UP PEF in iz predhodnih raziskav na to temo (Baloh in Mezgec 2017; Krmac 2019; Baloh in Bratož 2019). Zbiranje podatkov je potekalo v študijskih letih 2019/2020 in 2020/2021. Zagotovili smo anonimnost pridobljenih podatkov. Pri analizi podatkov smo uporabili primerjavo in kontrast, kjer smo želeli čim bolj poglobljeno prikazati preučevano situacijo.

\section{Rezultati in razprava}

\section{Ključni prehodi zamejskih študentov, ki se odločajo za študij na programu Predšolska vzgoja ali Razredni pouk na UP PEF in težave, s katerimi se soočajo ob prehodih}

Analizo ključnih prehodov in težav zamejskih študentov predstavljamo po kronološkem zaporedju, in sicer: pred vpisom, ob vpisu, med študijem in po zaključku študija.

\section{Prehod in težave zamejskih študentov pred vpisom}

Pred vpisom bodoči študentje ne zaznajo večjih težav. Bodoči maturanti šol s slovenskim učnim jezikom $v$ Italiji so pravočasno informirani, da vpis na univerze v Sloveniji poteka preko javnega razpisa, ki steče v zimskem času, ko interesenti oddajo prijavo. Ustrezne informacije dobijo $v$ medijih, šolah, pri šolskih svetovalcih Zavoda Republike Slovenije za šolstvo ter na univerzah. Kandidati, ki se zanimajo za študij v Sloveniji, se morajo z izbiro študija soočiti prej kot ostali vrstniki, ki načrtujejo študij v Italiji, saj vpisi v Italiji stečejo konec poletja. Nekaj je tehničnih težav pri izpolnjevanju spletne prijave, saj se pričakuje vnos podatkov po slovenskih standardih (npr. enotna matična številka občana (EMŠO), ocena mature, davčna številka ipd.). Težave lahko povzroči italijanski poštni sistem, saj je dostava dopisov čez mejo bistveno upočasnjena (Krmac 2019).

\section{Težave zamejskih študentov ob vpisu}

Ob vpisu morajo kandidati iz zamejstva priložiti ustrezno overovljeno dokumentacijo, pri tem ne nastajajo večje težave in zapleti. Na osnovi Lizbonske 
konvencije ni težav s priznavanjem stopnje šolanja za potrebe nadaljevanja študija (glej Mezgec 2019). Študentje iz zamejstva so celo v prednosti, ker vse italijanske srednješolske diplome dovoljujejo vpis na vse študijske programe, brez omejitev. To pravico se priznava tudi v primeru nadaljevanja študija v drugi državi. Če so študentje iz zamejstva zaključili šolanje na šolah s slovenskim učnim jezikom, jim ni potrebno dokazovati znanja iz slovenščine.

\section{Težave zamejskih študentov med študijem}

Študentje iz zamejstva niso izpostavili večjih težav med študijem (Krmac 2019). Nekaj manjših težav je povezanih z visokošolskim sistemom in visokošolsko terminologijo, ki pa odraža nove pojme, s katerimi se študentje soočajo (npr. izpitni roki, pavziranje, absolvent ipd.).

Poglavje zase je opravljanje pedagoške prakse. Študijska programa za vzgojitelja predšolske vzgoje in razrednega pouka namreč predvidevata, da študentje $z$ opravljanjem pedagoške prakse letno pridobijo določeno število kreditnih točk. Pedagoška praksa je za študente izrednega pomena, saj predstavlja njihovo prvo izkušnjo s pedagoškim poklicem in možnost povezave teoretičnega znanja s praktičnim. Lahko poteka znotraj posameznih specialnih didaktik v obliki hospitacij in nastopov študentov kot tudi v obliki strnjene prakse pri pouku, ki traja, odvisno od letnika, od dva do tri tedne.

Študijska praksa se izvaja po učnem načrtu in vanjo so poleg študenta vključeni še trije deležniki: koordinator, mentor na fakulteti in mentor $v$ vzgojno-izobraževalni instituciji. Program prakse oblikuje koordinator prakse, pri tem mu administrativno podporo nudijo strokovni delavci, mentorja pa sodelujeta pri izvedbi. Mentorji na fakulteti so univerzitetni profesorji, mentorji v vrtcu ali šoli vzgojitelji in učitelji praktiki, oboji pa sodelujejo pri vseh oblikah prakse ter študentom pomagajo na poti njihovega profesionalnega razvoja. Kot je zapisano v učbeniku Izzivi mentorstva (Valenčič Zuljan 2007), so za mentorja običajno izbrani posamezniki, ki svojo poklicno vlogo kakovostno opravljajo in imajo poleg tega ustrezne osebnostne lastnosti za delo z odraslimi.

Na praksi je pomembno tudi študentovo reflektivno preučevanje/raziskovanje praktičnega dela v razredu/vrtčevski skupini. Pri tem gre za spoznavanje, analiziranje in ovrednotenje lastne (študentove) pedagoške izkušnje $z$ namenom ugotavljanja stanja, kakovosti, pomanjkljivosti in možnosti izboljšave lastnega pedagoškega dela. Med pedagoško prakso, ki poteka znotraj posameznih specialnih didaktik in jo imenujemo integrirana praksa, študentje opazujejo strukturo dejavnosti na mikroravni (ustreznost ciljev, zaporedja faz, pedagoškega govora, metod idr.), med strnjeno pedagoško prakso pa vo- 
dijo dnevnik prakse, ki jih usmerja k načrtnemu opazovanju dogajanja $v$ razredu. V dnevniku študent načrtuje svoje sodelovanje pri pouku/učni uri, utemeljuje izbrane cilje, vsebine in metode, razmišlja o izvedbi opazovane učne ure in oblikuje nove predloge. Tako spozna učiteljevo/vzgojiteljevo delo, ga lahko pri tem opazuje in se v živo pouči o znanju in spretnostih, ki jih učitelj potrebuje pri svojem delu. Pri tem mu pomaga učitelj/vzgojitelj - mentor, ki ga usmerja, ga seznanja z vlogo učitelja/vzgojitelja v razredu/skupini, razredno klimo in na splošno z življenjem in delom $v$ šoli/vrtcu.

Projektna skupina v okviru projekta E. for ET/Socrates (Bijl idr. 2007 V Valenčič Zuljan 2007) je oblikovala devet mentorjevih kompetenc, po katerih, naj bi bil mentor: 1. spodbujevalec (supervizor) učenja in izkušenj, 2. posredovalec pomembnih znanj, 3. opazovalec, 4. posredovalec povratne informacije, 5. spodbujevalec ekspertnosti, 6. ocenjevalec, 7. organizator, 8. oseba, ki uveljavlja šolsko politiko, in 9. spodbujevalec razvoja mentorstva.

Rus Kolarjeva (2016) meni, da je mentorstvo zahtevna in zapletena naloga, ki od posameznega pedagoškega delavca zahteva posebne veščine, hkrati pa lahko neposredno vpliva na študentove dotedanje poglede in prihodnja dejanja, njegovo družbeno uveljavitev ter na osebnostno rast in nadaljnji profesionalni razvoj.

Študentje iz zamejstva, ki načrtujejo, da bi se po zaključku študija zaposlili v vzgojno-izobraževalnih ustanovah v Italiji, si prizadevajo, da bi prakso lahko opravljali v vrtcih in šolah v Italiji. Tako spoznajo svojo bodoče delovno okolje, gre pa tudi za priložnost, da bodoči delodajalci spoznajo svoje morebitne kandidate, bodoče učitelje. Izvajanje prakse v vrtcih v Sloveniji ponuja tudi priložnost za spoznavanje drugačnega vzgojno-izobraževalnega sistema; spoznanja lahko kasneje prenašajo $v$ domače delovno okolje, če se bodo $v$ njem dejansko tudi zaposlili.

Pri opravljanju prakse na šolah s slovenskim jezikom v Italiji pa se soočajo s/z težavami/izzivi: poznavanje programskih dokumentov, ki so osnova pedagoškemu načrtovanju (Indicazioni nazionali 2012), iskanje ustreznega mentorja prakse, saj UP PEF nima vzpostavljene mentorske mreže potencialnih mentorjev, pa tudi izpolnjevanje dnevnika prakse, katerega zahteve so prilagojene šolskemu sistemu in izvedbi pouka v Sloveniji, ki pa se od italijanskega razlikuje. Drugače je to $v$ vrtcu, kjer se sistema ne razlikujeta in študent lahko izpolni zahteve prakse, ki mu jih določa učni načrt prakse.

\section{Prehod in težave zamejskih študentov po zaključku študija}

Študentje, ki bi se radi po zaključku študija zaposlili v drugi državi kot vzgojitelji ali učitelji, morajo skozi postopek priznavanja poklicne kvalifikacije, saj 
gre za reguliran poklic (glej Mezgec 2019). V primerih, ko med državama ni bilateralnih sporazumov, priznavanje poteka skladno z evropsko zakonodajo oz. po t. i. splošnem sistemu. Slednji predvideva, da mora kandidat najprej pridobiti poklicno kvalifikacijo v eni državi, zato da lahko sproži postopek priznavanja v drugi (Direktiva 2005/36/ES Evropskega parlamenta in Sveta z dne 7. septembra 2005 o priznavanju poklicnih kvalifikacij 2005). Za primere, ki so predmet obravnave pričujočega prispevka, to pomeni, da mora diplomirani vzgojitelj predšolske vzgoje in magister razrednega pouka najprej pridobiti poklicno kvalifikacijo v Sloveniji. Za pridobitev poklicne kvalifikacije za poklic vzgojitelja je v Sloveniji potrebno zaključiti študijski program prve stopnje Predšolska vzgoja ali magistrski študijski program Predšolska vzgoja, Zgodnje učenje in poučevanje ali Zgodnje učenje (sicer se na delovnem mestu vzgojitelja po predhodnem opravljanju študijskega programa za izpopolnjevanje iz predšolske vzgoje lahko zaposli tudi, kdor ima strokovni naslov profesor ali magister profesor, kdor je končal univerzitetni študijski program s področja izobraževanja, umetnosti, humanističnih ved ali družboslovja, študijski program Socialno delo, magistrski študijski program druge stopnje $s$ področja izobraževanja, umetnosti, humanističnih ved ali družboslovja) (Pravilnik o izobrazbi vzgojiteljev predšolskih otrok in drugih strokovnih delavcev v programih za predšolske otroke in v prilagojenih programih za predšolske otroke s posebnimi potrebami 2012) in hkrati opravi strokovni izpit na področju vzgoje in izobraževanja.

Podobno je za pridobitev poklicne kvalifikacije učitelja razrednega pouka potrebno zaključiti magistrski študijski program Razredni pouk in opraviti strokovni izpit na področju vzgoje in izobraževanja (Odredba o smeri izobrazbe strokovnih delavcev $v$ devetletni osnovni šoli 1999).

Strokovni izpit je eden izmed pogojev za opravljanje vzgojno-izobraževalnega in drugega strokovnega dela v vrtcu oz. šoli. Opravljajo ga lahko kandidati, ki so delovne izkušnje pridobili kot pripravniki na področju vzgoje in izobraževanja, in kandidati, ki so delovne izkušnje pridobili z vzgojnoizobraževalnim delom v vrtcu oz. šoli.

Med pogoji za pristop k opravljanju strokovnega izpita je 840 ur opravljenega vzgojno-izobraževalnega dela v vrtcu oz. šoli. Delovne izkušnje v vzgoji in izobraževanju kandidat izkazuje s pogodbo o zaposlitvi oz. podjemno pogodbo. Kandidat lahko kot ustrezne delovne izkušnje za pristop k strokovnemu izpitu uveljavlja tudi:

- pedagoško prakso v deležu največ ene tretjine obsega pedagoške prakse, določene z izobraževalnim oz. študijskim programom, 
- organizirano neposredno aktivnost z namenom vzgoje in izobraževanja ter največ v obsegu 80 ur.

Poleg navedenega pa se za prijavo zahteva še pet uspešno opravljenih praktičnih nastopov v skladu s pravilnikom, ki ureja strokovne izpite (Ministrstvo za izobraževanje, znanost in šport b. I.). Pravilnik o strokovnem izpitu predvideva tudi možnost pridobivanja delovnih izkušenj $v$ tujini. Kot vzgojno-izobraževalno delo $v$ vrtcu ali šoli, ki ga mora izkazati kandidat za pristop k strokovnemu izpitu, se lahko upošteva primerljivo vzgojnoizobraževalno delo, opravljeno $v$ tujini. Kot ustrezno se upošteva vzgojnoizobraževalno delo $v$ akreditirani instituciji, ki sodi $v$ okvir nacionalnega izobraževalnega sistema države izvora. Vzgojno-izobraževalno delo mora biti opravljeno v državno priznanem oz. akreditiranem programu.

Za namen ovrednotenja ustreznosti vzgojno-izobraževalnega dela, opravljenega $v$ tujini, je potrebno vlogi priložiti dokazilo o pridobljenih delovnih izkušnjah, ki ga izda institucija, v kateri je kandidat opravljal vzgojnoizobraževalno delo. Iz dokazila morajo biti razvidni ime in priimek kandidata, naziv in sedež institucije ter podatki o akreditaciji, naziv programa in podatki o javni veljavnosti (akreditacija, državna veljavnost) ter podatki o delu (delovno mesto ali opis dela, predmet, predmetno področje).

Ne glede na obseg in program opravljenega vzgojno-izobraževalnega dela $v$ tujini mora kandidat za pristop k strokovnemu izpitu opraviti predpisanih pet praktičnih nastopov $v$ skladu s pravilnikom, ki ureja strokovne izpite $v$ vzgoji in izobraževanju, torej v ustreznem javnoveljavnem programu v Republiki Sloveniji.

$\checkmark$ tej fazi pa se pri prehodih zamejskih študentov pojavljajo težave, in sicer:

- kandidatom, ki se začasno zaposlijo kot nadomestni vzgojitelji ali učitelji v Italiji pred zaključkom študija, se ure dela, opravljene v Italiji, ne priznavajo kot ure, ki jih morajo opraviti za pristop k strokovnemu izpitu;

- ravno tako se te ure ne priznavajo za potrebe opravljanja prakse, ker potekajo izven časa, ki je predviden zanjo;

- vzgojno-izobraževalni zavodi v Sloveniji niso zainteresirani za sodelovanje oz. pripravništvo zamejskih študentov, saj vedo, da se bodo le-ti po opravljenem strokovnem izpitu zaposlili v šolah s slovenskim jezikom v Italiji - zato ta ciljna skupina diplomantov težje pridobi mesto pripravnika in se tudi težje dogovori za izvedbo petih nastopov;

- brez opravljenega strokovnega izpita v Sloveniji študentje ne morejo 
dobiti redne zaposlitve v Italiji, ker ne morejo sprožiti postopka priznavanja poklicne kvalifikacije.

Ko zamejski diplomanti pridobijo poklicno kvalifikacijo v Sloveniji, morajo sprožiti postopek njenega priznavanja v Italiji. Če bi radi poučevali v šolah s slovenskim učnim jezikom v Italiji, sta za postopek pristojna deželna izpostava Ministrstva za izobraževanje in Urad za slovenske šole pri Deželnem šolskem uradu. Če pristojni organ na osnovi pregledane vloge ugotovi, da ujemanje med izvorno poklicno kvalifikacijo in kvalifikacijami, ki so predvidene $v$ italijanski ureditvi, ni popolno, zahteva dopolnilne ukrepe (preizkus poklicne usposobljenosti ali prilagoditveno obdobje na italijanskih šolah) (Mezgec 2019).

Za diplomante magistrskega študijskega programa Razredni pouk, ki imajo opravljen strokovni izpit v Sloveniji, se navadno zahtevajo dopolnilni ukrepi. Kandidat lahko izbira med izpitom ali prilagoditvenim obdobjem v okviru pripravništva. Vsebina in/ali trajanje dopolnilnih ukrepov je/sta odvisna/odvisno tudi od morebitnih poklicnih izkušenj, ki jih kandidat ustrezno dokumentira. Vsebine izpita navadno zajemajo italijansko šolsko zakonodajo in italijanske učne načrte za osnovno šolo. Po uspešno opravljenem izpitu ali delovni praksi izda pristojni organ odločbo o priznavanju poklicne kvalifikacije. Priznavanje velja za poučevanje na šolah s slovenskim učnim jezikom v Italiji oz. na dvojezičnih italijansko-slovenskih šolah v Italiji (Mezgec 2019).

V primeru diplomantov programa Predšolska vzgoja velja opozoriti na razliko med trajanjem izobraževanja v Italiji in Sloveniji. Zato od slovenskih diplomiranih vzgojiteljev, ki imajo opravljen strokovni izpit v Sloveniji, pristojni italijanski organi navadno zahtevajo dopolnilne ukrepe, ki kompenzirajo razliko $v$ trajanju študijskega programa ( $v$ Sloveniji gre za triletni program, v Italiji za petletni magistrski program). Vsebine določijo glede na posamični primer, navadno zajemajo tudi italijansko šolsko zakonodajo in italijanske smernice za predšolsko vzgojo. Kandidat lahko izbira med izpitom ali delovno prakso. Vsebina in/ali trajanje dopolnilnih ukrepov je/sta odvisna/odvisno tudi od morebitnih poklicnih izkušenj, ki jih kandidat ustrezno dokumentira. Po uspešno opravljenem izpitu ali delovni praksi izda pristojni Urad za slovenske šole pri Deželnem šolskem uradu odločbo o priznavanju poklicne kvalifikacije. Tudi za diplomante magistrskega študijskega programa Zgodnje učenje, dodiplomskega študijskega programa Predšolska vzgoja ali doktorskega študijskega programa Zgodnje učenje in poučevanje se navadno zahtevajo dopolnilni ukrepi. Kandidat lahko izbira med izpitom ali prilagoditvenim obdobjem. Vsebine izpita navadno zajemajo italijansko šolsko zakono- 
dajo in italijanske smernice za predšolsko vzgojo. V obeh primerih priznavanje velja za poučevanje $v$ vrtcih s slovenskim učnim jezikom oz. $v$ dvojezičnih italijansko-slovenskih vrtcih v Italiji (Mezgec 2019, 26).

\section{Usposobljenost učiteljev in vzgojiteljev, ki so zaključili študij na UP PEF, za delo na šolah in v vrtcih s slovenskim učnim jezikom v Italiji}

Mrežo državnih šol s slovenskim učnim jezikom v Italiji sestavljajo vrtci, osnovne šole, srednje šole prve stopnje in srednje šole druge stopnje na Tržaškem in Goriškem. Gre za izobraževalne zavode, ki so del državnega šolskega sistema in delujejo po istih načelih ter pravilih, ki veljajo za italijanske državne šole. Učni načrti so ministrski in povsem enaki programom italijanskih šol z dodatnim predmetom slovenskega jezika in literature ter nekaterimi vsebinskimi dodatki pri zgodovini in zemljepisu. Izjema je dvojezični pouk v videmski pokrajini (Špetru), kjer pouk poteka v slovenskem in italijanskem jeziku (Bogatec 2020a).

Šolski sistem narodnostne skupnosti je poleg družine najpomembnejši medij socializacije. Izobraževalni sistem v slovenskem jeziku v Italiji je v sodobnem času pred novo preizkušnjo, saj enojezični položaj v teh šolah nikoli ni bil samoumeven, je pa $v$ slovenskem učnem prostoru $v$ Italiji čedalje več otrok, ki jim slovenščina ni prvi (materni) jezik (Bogatec 202ob), zato mora pouk jezika $v$ svojo poučevalno paradigmo vključevati medkulturnost in večjezičnost kot posebno sestavino kulture pouka. Pri jezikovnem pouku je neizbežno po eni strani upoštevati pravico otrok izobraževati se v slovenskem jeziku, s katerim ohranjajo svoj materni jezik in kulturo, po drugi strani pa je potrebno tenkočutno prisluhniti tudi drugim kulturam, ki neizbežno vstopajo v omenjeni šolski prostor. Melinc Mlekuževa (2019) meni, da imajo osrednjo vlogo pri razvijanju sporazumevalne zmožnosti mladih v slovenski skupnosti v Italiji vzgojno-izobraževalne ustanove, torej vrtci in šole, zato sta ustrezna zasnova pouka in usposobljenost vzgojiteljev in učiteljev ključnega pomena. Odgovornost šolstva je še toliko večja, ker sicer med nevodenimi dejavnostmi prihaja do zamenjave manjšinskega jezika z večinskim, kar vodi $\mathrm{h}$ krčenju priložnosti za komunikacijo v slovenskem jeziku.

Kot poudarja Larriveejeva (2000 v Baloh in Bratož 2019), učinkovito poučevanje predpostavlja veliko več kot zgolj nabiranje določenih spretnosti in strategij poučevanja. Odločitve, povezane s poučevanjem, se tesno povezujejo s prepričanji o učenju, poučevanju in razvoju. Kot menita Balohova in Bratoževa (2019), učinkovito poučevanje torej predpostavlja vlogo učitelja kot razmišljujočega oz. reflektivnega praktika, kar pomeni, da ta poklic zahteva določene osebnostne lastnosti, kot so odprtost, iskrenost, sodelovanje, etič- 
nost ipd., kar ugotavlja že Cencičeva (2015). Kot reflektivni praktik se učitelj z ravni, na kateri uporablja nabor pridobljenih znanj in spretnosti, pomakne na raven, na kateri je zmožen pridobljene znanje in spretnosti integrirati in spremeniti glede na dani kontekst (Larrivee 2000, 293). Reflektivno razmišljanje zahteva neprestano vrednotenje prepričanj, predpostavk in hipotez o podatkih ter informacijah, ki so nam na voljo, kot tudi kritično presojo različnih interpretacij podatkov (Dewey 1933 v Larrivee 2000). Kot menita Balohova in Bratoževa (2019), lahko v kontekstu večkulturnega in večjezičnega okolja slovenske narodnostne skupnosti v Italiji razvijanje medkulturnih kompetenc razumemo kot ključno za razumevanje vloge učitelja kot reflektivnega praktika.

Beštrova in Medveškova (2016) menita, da so izobraževalne možnosti lahko omejene, če vzgojitelj/učitelj ne upošteva etničnega, jezikovnega in kulturnega izvora sogovorca (otroka ali odrasle osebe). Nujno je torej, da je medkulturni vzgojitelj/učitelj tudi »raziskovalno radoveden« in preučuje lastno medkulturnost ter medkulturnost drugega, je pripravljen za pridobivanje tudi tovrstnega znanja in izkušenj. Avtorici sta mnenja, da bolj kot ima posameznik pozitiven odnos do kulturne raznolikosti, več znanja kot pridobi in ob tem razvija potrebne veščine, večkrat kot reflektira svoja ravnanja v medkulturnih situacijah, verjetneje je, da bo dosegel višjo stopnjo medkulturnih kompetenc.

Kot zapišeta Balohova in Bratoževa (2019), so učitelji in vzgojitelji v obmejnem prostoru $v$ razredu nenehno izpostavljeni situacijam, za katere je značilna izrazita jezikovna in kulturna raznolikost. Vloga učitelja kot reflektivnega praktika pa zahteva znanje, spretnosti in osebnostne lastnosti, s katerimi se bo učitelj sposoben soočiti z izzivi sodobnega razreda.

Verjetno od tod izvira mnenje študentov, diplomantov UP PEF o usposobljenosti za poklic učitelja in vzgojitelja na področju jezikovne ter medkulturne didaktike, ki je bilo izraženo v več raziskavah (Baloh in Mezgec 2017; Krmac 2019), saj imajo možnost raziskovanja in preizkušanja lastnih pedagoških veščin v vrtcih in šolah s slovenskim učnim jezikom v Italiji. Na tem področju ima UP PEF že dolgo tradicijo, ker poleg vzgoje kadrov v času študija že več let skrbi za stalno strokovno usposabljanje vzgojiteljev in učiteljev v Italiji. Izobraževanje otrok v medkulturnem in večjezičnem okolju mora biti namreč zasnovano na poznavanju realnosti jezikovnega in tudi kulturnega okvira, $v$ katerem tovrsten proces poteka, temu ustrezno pa ga je potrebno spremljati in prilagajati novejšim družbenim in zgodovinskim dogajanjem (Baloh 2018).

Kovačičeva (2007) meni, da je pouk v večjezičnem prostoru premalo učinkovit zaradi pomanjkanja specifičnega sistema izobraževanja ter usposablja- 
nja učiteljev in vzgojiteljev (op. avt.), ki bi slednjim nudil specifične kompetence za poučevanje slovenščine $v$ večjezičnem prostoru. Strokovno znanje in pedagoške izkušnje strokovnih delavcev niso kos zahtevnemu poučevanju v tem prostoru, kljub njihovemu prizadevanju za razvoj jezikovnih zmožnosti vseh otrok. Kritična točka pa je predvsem ta, da izobraževalne institucije $s$ slovenskim učnim jezikom v Italiji nimajo sebi prilagojenega lastnega kurikuluma z ustreznimi smernicami, ki bi upoštevale poseben položaj jezika v dvojezičnem območju in bi tako pripomogle pri pedagoškem delu in poučevanju slovenskega jezika ( $v$ zgodnjem otroštvu). Vzgojiteljem in učiteljem $\checkmark$ osnovnih šolah (za to stopnjo tudi izobražujemo študente na UP PEF) je na voljo in $v$ uporabo prevod italijanskih Kurikularnih smernic za otroški vrtec in za prvi šolski ciklus iz leta 2007, posodobljene smernice iz leta 2012 pa so na razpolago samo v italijanskem jeziku. Delo učitelja/vzgojitelja, pa tudi prepoznavanje novih pristopov pri učenju in poučevanju slovenskega jezika, je tako $v$ veliki meri prepuščeno strokovni presoji in avtonomiji učiteljev/vzgojiteljev.

Vendar pa naše raziskave (Baloh in Mezgec 2017; Krmac 2019) kažejo, da se študentje, ki študij zaključijo na UP PEF, čutijo dobro pripravljene za delo v izobraževalnih institucijah s slovenskim učnim jezikom v Italiji.

Večina vprašanih navaja, da ima izkušnje $z$ italijansko govorečimi otroki in $z$ otroki iz mešanih slovensko-italijanskih zakonov, vendar navajajo tudi izkušnje z rusko, s srbsko, hrvaško, špansko, z makedonsko, bošnjaško, romunsko, romsko govorečimi otroki. Večina vprašanih veliko pozornost pri poučevanju namenja predvsem kakovostni pripravi didaktičnega gradiva, saj ga v pomanjkanju splošno veljavnega učnega gradiva $v$ večji meri pripravljajo sami. Veliko se jih poslužuje podpornih strategij in didaktičnih iger, gradiva za spodbujanje pripovedovanja, kakovostnih slikanic in slikovnega gradiva, torej didaktičnih pripomočkov in strategij, ki so jih spoznali in/ali samostojno izdelali med študijem na UP PEF (Baloh in Mezgec 2017; Krmac 2019).

Kot meni Balohova (2019), tradicionalne metode učenja ne zadovoljujejo vse večjih potreb po ustvarjalni družbi. Nadomestiti jih morajo metode, kjer bo dovolj pozornosti posvečene tudi refleksiji, presoji, odzivu in otrokovi sodbi. V središču sodobnega izobraževanja mora biti inovativen otrok, opremljen z znanjem in orodji za ustvarjalno uporabo. $S$ tem je povezana tudi vloga sodobnega vzgojitelja/učitelja, ki v novi situaciji postane soustvarjalec in ne glavni akter izobraževanja. Nova vloga vzgojitelja/učitelja ne more biti zgolj prenos podatkov iz knjig v otrokovo glavo, temveč razvijanje kreativnosti, neodvisnosti mišljenja, kritičnega presojanja, reševanja težav, sodelovanja, sprejemanja odgovornosti in konstruktivnega obvladovanja čustev. 
Ob vsem tem pa sta nujno potrebni evalvacija in refleksija, brez katerih ni razvoja na osnovi preteklih izkušenj.

Z učinkovitimi didaktičnimi pristopi, tako Balohova (2019), individualizacijo in diferenciacijo, ki sta obvezni del poučevanja na vseh stopnjah, je potrebno ustvariti spodbudno učno okolje, v katerem so otroci motivirani, aktivni in lahko razvijajo svoja močna področja, pri šibkih pa odpravljajo pomanjkljivosti. Taka okolja spodbujajo samoregulacijo učenja, izkoriščanje učnih priložnosti, divergentno mišljenje in samorefleksijo.

Ravno zato je še posebej dragocen odgovor večine vprašanih (Baloh in Mezgec 2017; Krmac 2019), ki menijo, da se pri poučevanju v šolah s slovenskim učnim jezikom čutijo suverene predvsem za poučevanje slovenskega jezika (slovnice) in književnosti, ker jim je študij na UP PEF ponudil dovolj izzivov in strokovnega znanja. Pri tem moramo navesti, da so tak odgovor navedle predvsem študentke študijskih smeri Razredni pouk in Predšolska vzgoja.

\section{Predlogi za ublažitev težav pri prehodih zamejskih študentov na UP PEF}

$\checkmark$ nadaljevanju predstavljamo nabor predlogov, s katerimi bi lahko soudeleženi deležniki in nosilci interesov prispevali $\mathrm{k}$ lažjemu prehajanju zamejskih študentov med izobraževalnima sistemoma in zaposlitvenima svetovoma dveh mejnih držav.

Predlagamo, da bi bilo potrebno:

- Urediti prakso v zamejstvu, opolnomočiti mentorje in vzpostaviti mentorsko mrežo ter evidenco šol, saj, kot je zapisano v učbeniku Izzivi mentorstva (Valenčič Zuljan, 2007), domače in tuje raziskave ugotavljajo, da študenti in učitelji začetniki ocenjujejo, da ima mentor (skozi celotno poklicno izobraževanje) zelo velik vpliv na njihovo poklicno delovanje in razmišljanje. Da bo ta vpliv ustrezno izrabljen in bo dolgoročno spodbujal posameznikov profesionalni razvoj, sta pomembna vzpostavitev partnerstva med šolami in drugimi vzgojno-izobraževalnimi institucijami ter fakultetami, ki usposabljajo pedagoške delavce, in ustrezno definiranje mentorskega položaja. Prav tako pa je pomembna pripravljenost učiteljev za sprejem mentorske vloge.

- Razviti sistem tutorstva za čezmejne študente. Tutorstvo je, kot je zapisano v »Priročniku za tutorje Univerze na Primorskem« (2015), sistematično vodenje študentov skozi študij, pri čemer se ne osredotočamo strogo na njihov akademski razvoj, na težave pri študiju, temveč (in predvsem) tudi na njihov osebnosti razvoj. Tutorstvo je poslušanje, skupno iskanje poti pri reševanju problemov, pomoč študentu pri razvoju 
in iskanju profesionalne poti, študijskega načrta, načrtovanju in samovrednotenju svojega procesa učenja, umeščanju v socialne, profesionalne mreže idr. Na Univerzi na Primorskem (UP) sta razviti dve obliki tutorstva: študentsko in učiteljsko tutorstvo. Tutor študent lahko postane vsak redni ali izredni študent, ki je vpisan v študijske programe UP in ki je uspešno zaključil 1. letnik študija, ali študent, ki želi pomagati, svetovati itd. drugim študentom nižjih letnikov. Tutor učitelj na UP je lahko vsak visokošolski učitelj ali visokošolski sodelavec, ki je zaposlen na UP. Na lastno željo je tutor učitelj lahko tudi mladi raziskovalec. Tutorje učitelje imenuje senat fakultete, mandat traja štiri leta. Na UP PEF imamo tutorki visokošolski učiteljici, nimamo pa tutorjev študentov za zamejske študente, torej bi veljalo izpostaviti tudi tovrstno tutorstvo.

- Na pristojnem ministrstvu v Sloveniji urediti priznavanje začasnih zaposlitev (ur izvedenega dela $v$ neposrednem pedagoškem procesu), ki jih študentje opravijo v Italiji v naboru 840 ur in predstavljajo pogoj za pristop k strokovnemu izpitu $v$ Sloveniji.

- Na UP PEF že deluje klub alumnov UP PEF, ki je stičišče diplomantov in profesorjev UP PEF in temelji na krepitvi prepoznavnosti UP PEF v delovnih organizacijah in širši javnosti. Člani kluba alumnov UP PEF lahko postanejo diplomanti vseh študijskih programov fakultete. Smiselno bi bilo razmišljati, da bi v okviru kluba organizirali podskupino diplomantov, ki delujejo v zamejstvu, saj bi tako okrepili mrežo sodelovanja med sedanjimi in nekdanjimi študenti ter profesorji pripadniki slovenske narodnostne skupnosti v Italiji.

Za ublažitev težav zamejskih študentov po zaključku študija pa bi bilo potrebno zagotoviti:

- Osvežitev bilateralnih sporazumov za priznavanje diplom prve in druge stopnje.

- Vzpostavitev skupnega programa v sodelovanju med italijansko univerzo in slovensko univerzo - t. i. double degree. Ob zaključku tega programa študentje pridobijo dvojno diplomo, in sicer diplomo, ki ima status uradne listine tako v Sloveniji in Italiji, kar daje dostop do vseh pravic, ki pripadajo imetniku listine v obeh državah. V Italiji diplomati predšolske vzgoje in razrednega pouka $z$ diplomo pridobijo tudi poklicno kvalifikacijo, kar pomeni, da jim ni potrebno ločeno opravljati še strokovnega izpita. Posledično bi diplomanti, vpisani v double degree, pri- 
dobili naziv, ki v Italiji vključuje tudi poklicno kvalifikacijo, in jim ne bi bilo potrebno skozi postopek priznavanja nazivov. Istočasno pa bi Italija ohranila nadzor usposabljanja šolskega kadra tudi v manjšinskem jeziku. Odločitev za izobraževanje in usposabljanje v Sloveniji je med šolskim kadrom šol s slovenskim učnim jezikom v Italiji v porastu in predstavlja t. i. rešitev bottom up, ki so jo izbrali bodoči kadri šol s slovenskim učnim jezikom v Italiji. Ker je mreža šol s slovenskim učnim jezikom nujna za razvoj slovenske narodne skupnosti, je pomembno spremljati opisane dinamike in po potrebi urediti ustrezen normativni okvir, da ne pride do nepredvidenih anomalij med sistemoma, slovenskim in italijanskim, ki nista usklajena in ne komunicirata med seboj.

Razvidno je, da gre pri obeh kategorijah predlogov za iskanje sistemskih rešitev.

\section{Zaključek}

Zamejski študentje navajajo, da so pogosto v neugodnem položaju (Baloh in Mezgec 2017; Krmac 2019), ker med državama in ključnimi deležniki ni ustreznega dogovarjanja, ki bi prispevalo k lažjemu reševanju zapletov, ki nastajajo pri prehodih med dvema izobraževalnima sistemoma in dvema trgoma dela. Zamejski študentje predstavljajo pojav bottom up, ki ga državi urejata na osnovi evropske zakonodaje, čeprav bi pričakovali, da imata mejni državi usklajene bilateralne sporazume, ki bi zadoščali potrebam obmejnega prostora, ki ima svoje specifike ter samosvoje dinamike ter zato potrebuje namenske rešitve. Na tem področju državi zaostajata in jih pojavi bottom up, kot so zamejski študentje, prehitevajo.

$Z$ druge strani pa je $z$ vidika zaščite slovenske manjšine $v$ Italiji pomembno, da se ohrani pravica do izobraževanja šolnikov $v$ slovenskem jeziku na italijanskih univerzah. Trenutno študijska programa za vzgojitelje predšolske vzgoje in učitelje razrednega pouka v vrtcih in šolah s slovenskim učnim jezikom ponuja Univerza v Vidmu. Ostale univerze v Italiji nimajo programa za vzgojitelje in učitelje $v$ vrtcih in šolah s slovenskim učnim jezikom. Po drugi strani pa ima študij v Sloveniji številne prednosti, predvsem z vidika jezikovne kopeli, ki jo doživijo študentje med študijem in obštudijskimi dejavnostmi v Sloveniji. Slovenija je tudi v Strategiji internacionalizacije (Vlada Republike Slovenije 2016) zapisala, da je visoko šolstvo eden ključnih vzvodov za krepitev povezav s Slovenci po svetu. Smo mnenja, da bi bilo najsmotrneje strateško in odgovorno združiti prizadevanja obeh držav na tem področju, osvežiti bilateralne sporazume o vzajemnem priznavanju visokošolskih diplom 
ter pripraviti koncept double degree za študijska programa predšolske vzgoje in razrednega pouka, pri katerem bi sodelovale italijanske in slovenske univerze. Študentje bi se tako šolali tudi v italijanskem sistemu in s tem odpravili težave med prehodi, obenem pa bi izkusili študij v Sloveniji in slovenščini ter jezikovno kopel.

\section{Literatura}

Baloh, B. 2018. „Future Educators and Teachers' Views on Interculturalism and Slovenian Language Learning." V Innovative Teaching Models in the System of University Education: Opportunities, Challenges and Dilemmas, ur. E. Kopas-Vukašinović in J. Lepičnik-Vodopivec, 221-235. Jagodina: University of Kragujevac, Faculty of Education; Koper: University of Primorska, Faculty of Education.

—. 2019. »Zgodnje učenje in poučevanje slovenščine kot J2/JT.« V Doslidžennja navčannja, ur. S. Omelčenko, 47-64. Slovjansk: Donbaskij deržavnij pedagogičnij univerzitet.

Baloh, B., in S. Bratož. 2019. »Refleksija vloge učitelja v čezmejnem prostoru.« Razprave in gradivo 83:5-19.

Baloh, B., in M. Mezgec. 2017. »Procesi internacionalizacije visokega šolstva s čezmejne perspektive: izobraževanje zamejskih študentov na Pedagoški fakulteti Univerze na Primorskem. «V Vidiki internacionalizacije in kakovost $v$ visokem šolstvu, ur. S. Rutar, S. Čotar, T. Štemberger in S. Bratož, 93-100. Koper: Založba Univerze na Primorskem.

Bešter, R., in M. Medvešek. 2016. »Medkulturne kompetence učiteljev: primer poučevanja romskih učencev.« Sodobna pedagogika 67 (2): 26-44.

Bijl, N., G. Vermassen, L. Goethals, G. Walraevens, H. De Groote in H. Lauwereys. 2007. Gradivo projekta E. for ET/Socrates.

Bogatec, N. 2020a. »Analiza vpisov v vrtce in šole s slovenskim učnim jezikom oziroma dvojezičnim slovensko-italijanskim poukom v Italiji v obdobju od šolskega leta 2000/01 do šolskega leta 2019/20." Slovenski raziskovalni inštitut. http://www.slori.org/wp-content/uploads/2020/o1/Predstavitevjanuar-2020.pdf.

_ den: Mercator European Research Centre on Multilingualism and Language Learning.

Bufon, M. 2019a. "National Minorities, Border Communities and Crossborder Social Cohesion: A Case Study in Central Europe. "V International Conference Societies and Spaces in Contact:Between Convergence and Divergence; Book of Abstracts, ur. M. Bufon, K. Nemac in I. M. Cavaion, 78. Koper: Annales.

- 2019b. Lo spazio con/diviso: I'Alto Adriatico; un'area di contatto europea tra conflitti e integrazione. Rim: Aracne. 
Cencič, M. 2015. Izbrani pristopi k spodbujanju refleksije učiteljev. Koper: Založba Univerze na Primorskem.

Dewey, J. 1933. How We Think: A Restatement of Reflective Thinking to the Educative Process. Boston, MA: D. C. Heath Company.

Indicazioni nazionali per il curricolo della scuola dell'infanzia e del primo ciclo d'istruzione. 2012. Annali della pubblica istruzione 88 (posebna številka). http://www.indicazioninazionali.it/wp-content/uploads/2018/o8/ Indicazioni_Annali_Definitivo.pdf

Direktiva 2005/36/ES Evropskega parlamenta in Sveta z dne 7. septembra 2005 o priznavanju poklicnih kvalifikacij. 2006. Uradni list Evropske unije L 255.

Jagodic, D. 2014. „Cross-Border Residential Mobility on the Italian-Slovenian Borderland: A Transnational Laboratory for the Creation of European Space Or a New Hotbed of National Tensions? V The New European Frontiers: Social and Spatial (Re)Integration Issues in Multicultural and Border Regions, ur. M. Bufon, J. V. Minghi in A. Passi, 173-195. Newcastle upon Tyne: Cambridge Scholars.

Kovačič, K. 2007. Šest poučevalnih modelov za slovenščino v šolah in vrtcih v Furlaniji Julijski Krajini. Trst: Deželni zavod za pedagoško raziskovanje v Furlaniji Julijski krajini.

Krmac, N. 2019. »Analiza intervjujev čezmejnih študentov, ki študirajo na UP PEF: priloga 1 Modela informiranja in svetovanja čezmejnim študentom, EDUKA 2; čezmejno upravljanje izobraževanja.« Neobjavljeno gradivo.

Larrivee, B. 2000. »Transforming Teaching Practice: Becoming the Critically Reflective Teacher.« Reflective practice 1 (3): 293-307.

Melinc Mlekuž, M. 2019. »Sporazumevalna zmožnost v šolah s slovenskim učnim jezikom v Italiji.« Razprave in gradivo 83:67-82.

Mezgec, M. 2008. »ll lavoro transfrontaliero con la Slovenia.« V II mercato del lavoro in Friuli Venezia Giulia: rapporto 2008, 261-279. Trieste: Franco Angeli.

- 2019. „Cross-Border Higher Education for Primary School Teachers: The Case at the Italo-Slovene Border.« Razprave in gradivo 83:21-34.

Ministrstvo za izobraževanje, znanost in šport. B. I. »Strokovni izpit za delavce v vzgoji in izobraževanju.«https://www.gov.si/teme/strokovni-izpit-za -strokovne-delavce-v-vzgoji-in-izobrazevanju/.

Odredba o smeri izobrazbe strokovnih delavcev v devetletni osnovni šoli. 1999. Uradni list Republike Slovenije, št. 57. https://www.uradni-list.si/1/objava.jsp ?sop=1999-01-2721.

Pravilnik o izobrazbi vzgojiteljev predšolskih otrok in drugih strokovnih delavcev v programih za predšolske otroke in v prilagojenih programih za predšolske otroke s posebnimi potrebami. 2012. Uradni list Republike Slovenije, št. 92. https://www.uradni-list.si/glasilo-uradni-list-rs/vsebina/201201-3592? sop=2012-01-3592.

Rus Kolar, D. 2016. »Pogledi mentorjev na praktično pedagoško usposabljanje 
študentov pedagogike.« Revija za elementarno izobraževanje 9 (4): 87-104. Univerza na Primorskem. 2015. »Priročnik za tutorje Univerze na Primorskem.» http://www.fm-kp.si/Files/Studijske/2014_15/Prirocnik-za-tutorje_UP _-_junij_2015.pdf.

Valenčič Zuljan, M., ur. 2007. Izzivi mentorstva. Ljubljana: Pedagoška fakulteta. Vlada Republike Slovenije. 2016. Strategija internacionalizacije slovenskega visokega šolstva 2016-2020. Ur. K. Aškerc Veniger in A. Flander. Ljubljana: Center RS za mobilnost in evropske programe izobraževanja in usposabljanja in Ministrstvo RS za izobraževanje, znanost in šport.

Štemberger, T. 2020. Uvod v pedagoško raziskovanje. Koper: Založba univerze na Primorskem.

\section{Academic and Professional Transitions of Slovenian Cross-Border Students from Italy: The Case of University of Primorska, Faculty of Education}

The paper presents an ethnographic research on cross-border students of the Faculty of education of the University of Primorska. The analysis focuses on their transitions between two educational systems, starting with the transition from secondary school in Italy to higher education in Slovenia and concludes with the transition to the Italian labour market, once the study is completed. The aim of the paper is to analyse the gaps that cross-border students are facing during the transitions and suggest which steps can be improved in order to avoid cross border students becoming victims of the two systems.

Keywords: cross-border students, recognition of qualifications, professional recognition, internship, cross-border area 